\title{
Australian energy diplomacy
}

\section{Christian Downie}

To cite this article: Christian Downie (2019) Australian energy diplomacy, Australian Journal of International Affairs, 73:2, 119-125, DOI: 10.1080/10357718.2018.1534941

To link to this article: https://doi.org/10.1080/10357718.2018.1534941

\section{Published online: 17 Oct 2018.}

Submit your article to this journal ๘

Џ Article views: 174

View Crossmark data ¿ 


\section{Australian energy diplomacy}

\section{Christian Downie}

School of Regulation and Global Governance (RegNet), The Australian National University, Canberra, Australia

\begin{abstract}
While Australia is considered an energy superpower, Australian foreign policy has often overlooked energy diplomacy. Given the transformations taking place in global energy markets, the time is ripe to begin a policy discussion in Australia on energy diplomacy. I argue that Australian diplomatic efforts should broaden beyond a historical focus on promoting fossil fuels and securing export markets, to driving global energy governance reforms through the G20. This will not only help to ensure that the international energy architecture is capable of achieving governance objectives around energy security, energy access and climate change, but significantly, it will also help Australia to achieve broader foreign policy goals, such as ensuring emerging economies become responsible stakeholders within the international system.
\end{abstract}

\section{KEYWORDS}

Energy; diplomacy; Australia; G20; foreign policy

\section{Introduction}

Successive federal governments have declared Australia to be an 'energy superpower'. The 2017 Foreign Policy White Paper is the most recent example highlighting the size of Australia's energy exports (Australian Government 2017, 52). This is no surprise given that Australia is the largest exporter of coal in the world, and yearly export earnings from energy resources are projected to reach $\$ 114$ billion by the end of the decade (Australian Government 2015). While Australia may not match the output of the largest fossil fuel producers in the world, such as the US, Russia, or Saudi Arabia, it is no energy minnow, both in terms of fossil fuels and increasingly renewable energy as well (Australian Government 2015; IEA 2017c).

However, Australian foreign policy has often overlooked energy diplomacy. In the US, terms such as 'energy diplomacy' are now a popular part of the policy lexicon (Boersma and Johnson 2018). In 2012 Hilary Clinton, as Secretary of State, devoted an entire speech to the topic and established the Bureau of Energy Resources within the Department of State (Clinton 2012). Yet in Australia little attention has been given to the concept, including how energy diplomacy might interact with broader foreign policy objectives. In recent decades the diplomatic focus has typically been confined to securing Australian export markets in Asia, aside from diplomatic efforts in the 1970s and 1980s to build a network of nuclear safeguards as a precondition for uranium exports (Clarke 2008; Leaver 2007).

CONTACT Christian Downie christian.downie@anu.edu.au $\Theta$ School of Regulation and Global Governance (RegNet), The Australian National University, Canberra, ACT 0200, Australia 
In this commentary, I argue that given the transformations taking place in global energy markets, the time is ripe to begin a policy discussion in Australia on energy diplomacy. In particular, to consider what is energy diplomacy? What should Australian energy diplomacy focus on? And, how can it support broader Australian foreign policy objectives? In considering these questions, I argue that Australian energy diplomacy will need to broaden beyond a historical focus on promoting fossil fuels and securing export markets, to driving efforts that improve global energy governance via the Group of Twenty (G20). This is because in the absence of a world energy organisation the G20 is best placed to steer such reforms. This will not only help to ensure that the international energy architecture is capable of achieving governance objectives around energy security, energy access and climate change, but significantly, it will also help Australia to achieve related foreign policy goals, such as ensuring emerging economies become responsible stakeholders within the international system.

\section{What is energy diplomacy?}

While the term energy diplomacy is widely used in many jurisdictions its meaning varies. Broadly, two conceptualisations can be identified, one that focuses on the geopolitical dimension of energy diplomacy, and another that focusses on the governance dimension (Goldthau 2010; Herranz-Surrallés 2016). First, the term energy diplomacy has historically been associated with geopolitics where energy security is viewed as a geopolitical problem. For large energy consumers this is reflected in diplomatic efforts to secure energy supplies, such as China's oil diplomacy in Africa. And for large energy producers, it is reflected in the use of diplomacy to improve access to global markets, such as Australia's efforts to ensure access to markets for coal and natural gas.

However, scholars have questioned how influential diplomatic efforts are at securing access to resources for supply, or to securing access to markets for export. For example, a recent review of US energy diplomacy concluded that:

US diplomats have relatively modest influence over US resources-how many are produced and where they are sold-which, at the end of the day, is decided by market participants, based on price signals, and subject to a wide array of government regulations, none of which are tied directly to diplomacy. (Boersma and Johnson 2018, 20)

Of course, that is not to say that energy diplomacy conceived of in terms of geopolitics has no influence, in certain circumstances it will, especially when markets are not liberalised, but its influence can be overstated.

A second conceptualisation of energy diplomacy, though the term is not always employed explicitly, focusses on the global governance dimension of energy (Herranz-Surrallés 2016). According to this view, diplomatic efforts should seek to ensure that the global energy system is capable of governing energy in a way that addresses key governance objectives around energy security, energy access and climate change (Dubash and Florini 2011; Van de Graaf and Colgan 2016). This can include strengthening multilateral institutions to: ensure that they are sufficiently resourced to underwrite energy security; that they prioritise initiatives to address the 1.1 billion people without access to electricity (IEA 2017a); and that they tackle climate change by putting in place mechanisms that facilitate a clean energy transition. 


\section{Transformations in global energy markets}

While both conceptualisations of energy diplomacy have merit, and are by no means mutually exclusive, there is good reason to suspect that the time has come for diplomatic efforts to invest more in improving global energy governance, than in solving historical geopolitical problems. This is because global energy markets are being transformed and the current international energy architecture is failing to keep up.

Two disruptive trends stand out. First, the sources of global energy production and consumption are being recast in ways that were unimaginable a decade ago. The US has now overtaken Saudi Arabia and Russia to be the largest producer of oil and gas in the world, and it is on track to be a net exporter of oil as a result of the shale revolution (IEA 2017c). In 2015 the US overturned a ban on the export of crude oil that had been in place for 40 years (GAO 2014). Meanwhile China is now the largest energy consumer in the world having overtaken the US, and energy demand is ballooning in India and across southeast Asia (IEA 2017c). As a result, much of the international energy architecture needs to be recalibrated to reflect these changing patterns, including the International Energy Agency (IEA) discussed below.

Second, climate change is forcing governments around the world to re-think energy production and consumption. As the source of more than two-thirds of global greenhouse gas emissions, it is not hard to see why transforming the energy sector will be crucial to efforts to address climate change (IEA 2015). Yet just over 80 per cent of the world's primary energy supply continues to be met by fossil fuels, and strikingly, this has hardly changed in 40 years (IEA 2017b). Accordingly, the boom in renewable energy around the world is likely to further disrupt the energy landscape, with the IEA projecting that renewables could be the world's largest source of electricity supply before 2030 (IEA 2016, 397). This will have implications for the governance of energy as new institutions and frameworks are required to manage a clean energy transition.

The scholarly consensus is that the global energy system is failing to keep up with these transformations. Unlike other global policy areas, such as trade, health or finance, there is no single international organisation that governs energy to match the World Trade Organization, the World Health Organization, or the International Monetary Fund. What there is, is a jumble of partially overlapping non-hierarchical institutions, often with conflicting goals that are better suited to addressing the energy challenges of the last century, rather than the challenges of this one (Florini 2012; Florini and Sovacool 2009; Hirst and Froggatt 2012; Van de Graaf and Colgan 2016). The IEA is the most conspicuous example. Established in 1974 to represent the world's largest energy consumers, today many of the top consuming nations, including China, India and Brazil, are not formal members. In addition, its treaty mandate remains narrowly confined to oil supply disruptions rather than driving a clean energy transition (Downie 2015a).

\section{What should Australian energy diplomacy focus on?}

In order to keep up with these profound changes in global energy markets, Australian energy diplomacy will need to broaden beyond a historical focus on promoting fossil fuels and securing export markets, to driving efforts that improve global energy governance via the G20. The G20 is the body best placed to steer global energy governance 
reform. G20 members together account for 80 per cent of the world's primary energy demand, including 95 per cent of its coal demand and almost three quarters of its oil and gas demand, and 85 per cent of global investment in renewables (IEA/IRENA 2017). And, states are already turning to the G20 in the absence of a formal world energy organisation or any likelihood that one will be created soon (Van de Graaf and Colgan 2016). Indeed at the G20 Summit in Brisbane in 2014 world leaders for the first time agreed that the 'international energy architecture needs to reflect better the changing realities of the world energy landscape' (G20 2014).

Australia is well-placed to take on a leadership role in the G20. As host of the G20 in 2014, Australia played a key role in putting the reform of the international energy architecture on the agenda. In addition, without the US or China leading on the issue, or a coalition of states, such as the BRICS, which existing evidence suggests is unlikely given the BRICs do not have a coherent preference on global energy governance reform (Downie 2015b), Australia could take on the role of an entrepreneurial middle power to broker compromise positions between the major powers for reforming the existing international energy architecture.

Specifically, Australia energy diplomacy could focus on three areas that will improve global energy governance and are consistent with the 2014 G20 agreement. First, Australia should use the G20 to strengthen existing multilateral institutions. One of the key principles agreed to by the G20 in 2014 was to ensure that international energy institutions [are] more representative and inclusive of emerging and developing economies' (G20 2014). To a large extent, this referred to reforming the IEA, which is considered by many nations to be out of date given that it does not include some of the largest energy consumers among its members. In this context, Australian energy diplomacy should focus on furthering these negotiations to strengthen existing multilateral institutions, which have so far failed to produce substantive results.

Second, Australia should also use the G20 to improve coordination between the various international energy organisations that often have conflicting goals in order to bring greater coherence to the international energy architecture. For example, of the multitude of energy organisations that exist today, some focus on the production of fossil fuels, such as OPEC, others on the consumption of fossil fuels, such as the IEA, others still on renewable energy such as the recently established International Renewable Energy Agency (IRENA), or on energy investment, such as the Energy Charter Treaty organization (ECT) - and these are just a sample (Florini and Sovacool 2009). While attempts have been made to improve coordination between these organisations, including between OPEC and the IEA, much more needs to be done if the global energy system is going to achieve global governance objectives around energy security, energy access or climate change.

Third, Australian energy diplomacy should promote collaboration between G20 member states' national energy policies. The G20 has already shown the potential of collaboration in other domains such as finance, when following the global financial crisis in 2008 G20 leaders agreed to coordinate their fiscal and monetary policies thereby ameliorating the worst effects of the crisis (Drezner 2014). Similar steps could be taken in the domain of energy. For instance, in 2009 G20 leaders announced that they would 'rationalize and phase out over the medium term inefficient fossil fuel subsidies' (G20 2009). That is, they would phase out government policies that support the production or consumption 
of oil, gas and coal, which can include direct subsidies such as loans, and/or indirect subsidies such as price regulation. Yet despite their significant contribution to greenhouse gas emissions, G20 countries have so far failed to sufficiently coordinate national efforts to phase out such subsidies. In fact, for the year 2014, the IEA estimated that fossil fuel consumption subsidies totalled almost $\$ 500$ billion for 2014 , while the IMF, which takes into account production subsidies, estimated that they could total over $\$ 5$ trillion (Van de Graaf and van Asselt 2017).

However, if Australian energy diplomacy is to effectively pursue a governance agenda then it must back up its rhetoric with actions. In other words, Australia must demonstrate that it is a constructive international partner in the domain of energy. In recent years, it is not clear that it has been. Continuing with the example of fossil fuel subsidies, in 2013 the G20 introduced a peer review process, in which members could voluntarily share information to evaluate the extent of their fossil fuel subsidies (G20 2013). While several G20 countries have now completed or agreed to participate in the peer review process, including the US and China, Australia has so far failed to do so (OECD 2016). More broadly, Australia's inability over the last decade to develop and maintain a strategy to limit and reduce greenhouse gas emissions is also undermining its diplomatic standing. Such issues will need to be rectified domestically if Australia is to be successful internationally.

\section{How can Australian energy diplomacy support broader foreign policy objectives?}

Broadening Australian energy diplomacy will enhance Australia's capacity to achieve related foreign policy goals. These goals include: ensuring Australia has a seat at the G20; encouraging emerging economies to become responsible international stakeholders; and restricting the growth of conflict between major powers.

First, Australia has had a long standing objective to ensure that the G20 remains an effective and legitimate forum, given that Australia's 'interests are advanced by having a voice at the G20' (Australian Government 2017, 57). This is especially important given that there is no guarantee that Australia would have a seat at the table of an alternative G8-plus type forum if the G20 was disbanded (Downie 2017, 1497). Hence to the extent that Australia can succeed in steering global energy governance reforms through the G20, it will help to bolster the legitimacy of the G20 and Australia's membership of it.

Second, efforts to reform the IEA membership by bringing nations, such as China, India and Indonesia on board, will support Australia's foreign policy goal to ensure that these nations become responsible stakeholders within the international system. As the 2017 Foreign Policy White Paper stated, 'Australia encourages reform to international institutions to make them more effective and responsive, and to better reflect the economic weight of emerging economies' (Australian Government 2017, 58). Australia has successfully pursued this objective in the domain of finance by advocating for IMF reform, and Australian energy diplomacy should do the same for IEA reform.

Finally, Australia has historically invested resources in attempting to restrict the growth of economic conflict between major powers, such as the US and Japan, and more recently the US and China, in order to maintain a peaceful multilateral international order in which it can prosper (Cooper, Higgott, and Nossal 1993). To the extent that Australian energy 
diplomacy shifts away from a narrow self-interested focus on export promotion, to improving global energy governance in ways that allow major powers to cooperate on critical issues, such as the rules governing oil markets, or subsidies for fossil fuels, it is also likely to ease rivalries and reduce potential conflict.

\section{Acknowledgments}

I am very grateful to Howard Bamsey and Tim Boersma for their feedback on this commentary.

\section{Disclosure statement}

No potential conflict of interest was reported by the author.

\section{Funding}

This work was supported by an Australian Research Council Discovery Early Career Researcher Award (DE180100898).

\section{Notes on contributor}

Christian Downie is an Australian Research Council DECRA Fellow in the School of Regulation and Global Governance at The Australian National University. He was previously a Vice Chancellor's Postdoctoral Fellow at the University of New South Wales. Christian has worked as a foreign policy advisor to the Australian Government's Department of the Prime Minister and Cabinet and a climate policy advisor to the Department of Climate Change.

\section{ORCID}

Christian Downie (D) http://orcid.org/0000-0002-1559-1814

\section{References}

Australian Government. 2015. Energy White Paper. Canberra: Department of Industry and Science. Australian Government. 2017. 2017 Foreign Policy White Paper. Canberra: Department of Foreign Affairs and Trade.

Boersma, T., and C. Johnson. 2018. U.S. Energy Diplomacy. New York: Columbia Center on Global Energy Policy.

Clarke, M. 2008. "Refashioning Australia's Nuclear Bargain?” The Nonproliferation Review 15: 311334.

Clinton, H. 2012. Hillary Clinton Gives Energy Diplomacy Speech at Georgetown. Washington, DC: Georgetown University.

Cooper, A. F., R. Higgott, and K. Nossal. 1993. Relocating Middle Powers: Australia and Canada in a Changing World Order. Melbourne: Melbourne University Press.

Downie, C. 2015a. "Global Energy Governance in the G-20: States, Coalitions, and Crises." Global Governance 21: 475-492.

Downie, C. 2015b. "Global Energy Governance: Do the BRICs Have the Energy to Drive Reform?" International Affairs 91: 799-812.

Downie, C. 2017. "One in 20: The G20, Middle Powers and Global Governance Reform." Third World Quarterly 38: 1493-1510. 
Drezner, D. 2014. The System Worked: How the World Stopped Another Great Depression. Oxford: Oxford University Press.

Dubash, N. K., and A. Florini. 2011. "Mapping Global Energy Governance." Global Policy 2: 6-18. Florini, A. 2012. "The Peculiar Politics of Energy.” Ethics \& International Affairs 26: 293-309.

Florini, A., and B. K. Sovacool. 2009. "Who Governs Energy? The Challenges Facing Global Energy Governance." Energy Policy 37: 5239-5248.

G20. 2009. G20 Leaders Statement: The Pittsburgh Summit, September 24-25. G20 Information Centre.

G20. 2013. G20 Leaders' Declaration. Saint Petersburg Summit, September 5-6. G20.

G20. 2014. G20 Principles on Energy Collaboration. Brisbane: G20 Leaders' Summit, November 1516.

GAO. 2014. "Changing Crude Oil Markets: Allowing Exports Could Reduce Consumer Fuel Prices, and the Size of the Strategic Reserves Should be Reexamined." United States Government Accountability Office.

Goldthau, A. 2010. "Energy Diplomacy in Trade and Investment of Oil and Gas." In Global Energy Governance. The New Rules of the Game, edited by A. Goldthau, and J. M. Witte, 25-47. Washington, DC: Brookings Press.

Herranz-Surrallés, A. 2016. “An Emerging EU Energy Diplomacy? Discursive Shifts, Enduring Practices.” Journal of European Public Policy 23: 1386-1405.

Hirst, N., and A. Froggatt. 2012. The Reform of Global Energy Governance. London: Grantham Institute for Climate Change.

IEA. 2015. Energy and Climate Change. Paris: International Energy Agency.

IEA. 2016. World Energy Outlook 2016. Paris: International Energy Agency.

IEA. 2017a. Energy Access Outlook 2017. Paris: International Energy Agency.

IEA. 2017b. Key World Energy Statistics. Paris: International Energy Agency.

IEA. 2017c. World Energy Outlook. Paris: International Energy Agency.

IEA/IRENA. 2017. Perspectives for the Energy Transition - Investment Needs for a low-Carbon Energy System. Paris: IEA and IRENA.

Leaver, R. 2007. "Australia and Asia-Pacific Energy Security: The Rhymes of History.” In Energy Security in Asia, edited by M. Wesley, 91-111. New York: Routledge.

OECD. 2016. "OECD Welcomes Ground-Breaking Peer Reviews by China and US of Their Fossil Fuel Subsidies." Green Growth and Sustainable Development [Online]. http://www.oecd.org/ greengrowth/oecd-welcomes-ground-breaking-peer-reviews-by-china-and-us-of-their-fossilfuel-subsidies.htm.

Van de Graaf, T., and J. Colgan. 2016. "Global Energy Governance: A Review and Research Agenda." Palgrave Communications 2: 15047.

Van de Graaf, T., and H. van Asselt. 2017. "Introduction to the Special Issue: Energy Subsidies at the Intersection of Climate, Energy, and Trade Governance." International Environmental Agreements: Politics, Law and Economics 17: 313-326. 